\title{
VIDEO PSIKOEDUKASI SEBAGAI PSYCHOLOGICAL FIRST AID DALAM MENOLONG ANAK KORBAN SEXUAL ABUSE
}

\author{
Yustina Gemilang*, Magdalena Pranata Santoso' \\ Program Studi Pendidikan Guru Sekolah Dasar, Universitas Kristen Petra \\ Jl. Siwalankerto 121-131, Surabaya \\ E-mail: *justinagemilang@gmail.com; ${ }^{2}$ magdaps@petra.ac.id \\ *Penulis korespondensi
}

\begin{abstract}
ABSTRAK
Kasus kekerasan seksual pada anak terus meningkat. Anak-anak merupakan kelompok yang paling sering menjadi korban terhadap sexual abuse. Tindakan sexual abuse memberikan dampak jangka pendek dan panjang pada anak. Trauma pada anak yang mengalami sexual abuse akan mereka alami seumur hidupnya. Trauma akibat sexual abuse pada anak akan semakin sulit dipulihkan jika tidak segera ditangani. Anak-anak yang menjadi korban sexual abuse perlu segera ditolong. Pendekatan yang bisa dipakai untuk memberi dukungan psikologis pertama pada anak yaitu Psychological First Aid (PFA). PFA untuk anak-anak berkontribusi pada pencegahan jangka pendek dan jangka panjang masalah psikologis seperti trauma. Melakukan PFA pada anak yang menjadi korban sexual abuse dapat mengurangi risiko gangguan mental, meningkatkan self-healing, dan membangun harapan pada anak. Tujuan dari penelitian ini untuk menolong anak korban sexual abuse mendapatkan dukungan psikologis pertama. Penelitian ini menggunakan metode pengumpulan data berupa wawancara dengan pakar dan studi literatur. Subyek yang digunakan dalam penelitian ini adalah anak korban sexual abuse usia 10-12 tahun dan penyintas sexual abuse. Disimpulkan video ini efektif menolong anak korban sexual abuse dalam memberikan dukungan psikologis pertama.
\end{abstract}

Kata kunci: Kekerasan Seksual Anak, Pertolongan Pertama Psikologis, Pemulihan Trauma, PFA.

\begin{abstract}
Cases of sexual violence against children continue to increase. Children are the group who most frequently experience sexual abuse. Sexual abuse has a short-and long-term impact on children, in which they will experience trauma, especially those who experience sexual abuse throughout their lives. Trauma due to sexual abuse in children will be more difficult to recover from if not treated immediately. Children who are victims of sexual abuse need to be helped immediately. An approach that can be used to provide initial psychological support to children is called Psychological First Aid (PFA). PFA for children contributes to the short-term and long-term prevention of psychological problems such as trauma. Conducting PFA on children who are victims of sexual abuse can reduce the risk of mental disorders, increase selfhealing, and build hope in children. The aim of this research is to help child victims of sexual abuse to receive initial psychological support through psycho-educational videos. The data collection methods used in this study were interviews with experts and literature studies. The subjects in this study were children, aged 10-12, who were
\end{abstract}


Aletheia Christian Educators Journal, Vol. 2, No. 1, April 2021, 105-124

victims of sexual abuse and survivors of sexual abuse. It was found that the psychoeducational video produced is effective in helping child victims of sexual abuse though providing initial psychological support.

Keywords: Child Sexual Abuse. Psychological First Aid, Trauma Healing.

\section{PENDAHULUAN}

Kekerasan pada anak di Indonesia semakin banyak terjadi. Data dari Sistem Informasi Online Perlindungan Perempuan dan Anak (Simfoni PPA) mencatat bahwa sejak Januari hingga 17 Juli 2020, terdapat hampir 3.928 kasus kekerasan terhadap anak. Kekerasan yang terjadi berupa kekerasan seksual, kekerasan fisik maupun kekerasan emosional, tetapi hampir 55 persen yang paling banyak terjadi adalah kekerasan seksual. Data ini juga menunjukkan bahwa kasus kekerasan seksual (sexual abuse) pada anak di Indonesia sangat tinggi.

Kasus kekerasan seksual pada anak terus meningkat. Lembaga Perlindungan Saksi dan Korban (LPSK) mencatat di tahun 2019, kekerasan seksual pada anak meningkat 70 persen dibandingkan tahun sebelumnya (Lembaga perlindungan saksi dan korban, diakses pada 31 Agustus 2020). Ini merupakan fenomena yang semakin memprihatinkan di Indonesia sekarang dan harus menjadi perhatian bagi kita.

Kekerasan seksual pada anak meningkat sebanyak 75 persen selama pandemi virus corona. Berdasarkan Data Kementerian Pemberdayaan Perempuan dan Perlindungan Anak (KPPPA), ditemukan kasus kekerasan seksual terhadap anak dalam keluarga sebanyak 700 kasus atau meningkat sebanyak 75 persen sedangkan kasus kekerasan seksual secara umum meningkat sebesar 55 persen, dari 2.367 pada akhir 2019 menjadi 3.928 kasus pada Januari hingga Juli 2020 (VOA, 2020).

Peningkatan kekerasan seksual pada anak selama pandemi corona menunjukkan bahwa kekerasan ini dapat dilakukan oleh siapapun dan dimanapun. Bahkan dapat dilakukan oleh orang-orang yang memiliki relasi dekat dengan korban. Lingkungan keluarga yang seharusnya menjadi tempat yang aman dan nyaman bagi anak, berubah menjadi tempat yang menakutkan bagi anak. Kekerasan seksual pada anak yang dilakukan oleh orang terdekat, akan sangat melukai anak secara mendalam.

Anak-anak merupakan kelompok yang paling sering menjadi korban terhadap sexual abuse. Hal ini terjadi karena anakanak selalu diposisikan sebagai sosok yang lemah dan tidak berdaya. Anak-anak rentan untuk menjadi korban sexual abuse karena tingkat melindungi diri sendiri masih sangat terbatas. Kekerasan seksual (sexual abuse) pada anak dapat terjadi di mana saja, kapan saja serta dapat dilakukan oleh siapa saja, baik itu anggota keluarga, pihak sekolah, maupun orang lain (Ocviyanti, Dwiana, \& Khusen, 2018).

Tindakan sexual abuse membawa dampak emosional dan fisik pada anak. Secara emosional, anak sebagai korban sexual abuse akan mengalami stres, depresi, goncangan jiwa, adanya perasaan bersalah dan menyalahkan diri sendiri, rasa takut untuk berhubungan dengan orang lain, teringat bayangan kejadian di mana anak menerima sexual abuse, mimpi buruk, dan insomnia (Ocviyanti, Dwiana, \& Khusen, 2018). Secara fisik, korban akan mengalami penurunan nafsu makan, sulit tidur, sakit kepala, tidak nyaman di sekitar vagina atau alat kelamin, berisiko tertular penyakit menular seksual, luka di tubuh akibat perkosaan dengan kekerasan, kehamilan yang tidak diinginkan, dan sebagainya 
(Noviana, 2015).

Tindakan sexual abuse memberikan dampak jangka pendek dan panjang pada anak. Pada dampak jangka pendek, anak akan mengalami mimpi buruk, ketakutan yang berlebihan pada orang lain, dan konsentrasi menurun yang akhirnya akan berdampak pada kesehatan. Lalu jangka panjangnya, ketika dewasa, ia akan mengalami fobia pada hubungan seks atau bahkan akan terbiasa dengan kekerasan sebelum melakukan hubungan seksual (Ocviyanti, Dwiana, \& Khusen, 2018).

Trauma pada anak yang mengalami sexual abuse akan mereka alami seumur hidupnya (Ginting, 2020). Seringkali anak-anak yang mengalami sexual abuse tidak menyadari bahwa tindakan yang mereka terima merupakan bentuk sexual abuse sehingga mereka baru sadar kalau mereka adalah korban, ketika mereka sudah beranjak dewasa, dan mengalami trauma yang lebih parah yaitu Post Traumatic Stress Disorder (PTSD). Trauma akibat sexual abuse pada anak akan semakin sulit dipulihkan jika tidak segera ditangani. Seperti luka saat terjatuh, jika tidak segera diobati dan diberikan obat merah, maka luka itu akan semakin lama untuk pulih dan disembuhkan. Luka itu akan terus menganga dan beresiko terkena infeksi yang dapat semakin memperparah kondisinya.

Anak-anak yang menjadi korban sexual abuse perlu segera ditolong. Sama halnya luka saat terjatuh, jika tidak segera ditangani maka proses pemulihannya akan sangat lama. Ketika menolong anak-anak yang menjadi korban sexual abuse, kita juga perlu melakukan tindakan pertolongan pertama. Pendekatan yang bisa dipakai untuk memberi dukungan psikologis pertama pada anak yaitu Psychological First Aid (PFA).

Psychological First Aid (PFA) adalah pertolongan pertama untuk menolong anakanak dalam krisis mengatasi traumanya. Anak yang menjadi korban sexual abuse juga masuk dalam kategori anak dalam krisis. Psychological First Aid (PFA) yang diberikan pada anak yang menjadi korban sexual abuse, seperti obat merah yang diberikan secara langsung saat anak terjatuh atau terluka. Itu akan sangat menolong anak mengobati luka hatinya.

PFA untuk anak-anak berkontribusi pada pencegahan jangka pendek dan jangka panjang masalah psikologis seperti trauma (Terlonge, 2013). Pemulihan pada anak korban sexual abuse bisa cepat meningkat ketika ada dukungan yang diberikan secara tepat di tahap awal, dan risiko masalah kesehatan mental jangka panjang akan berkurang secara drastis. Ada beberapa alasan penting untuk melakukan PFA pada anak yang menjadi korban sexual abuse, yaitu mengurangi risiko gangguan mental, meningkatkan self-healing, dan membangun harapan pada anak (Susanto, 2019).

Video menjadi salah satu alat yang dapat dipakai dalam memberikan dukungan psikologis pertama pada anak korban sexual abuse. Menurut Computer Technology Research (CTR) sebagaimana dikutip oleh Erianti \& Adila (2019, p.216), menyatakan bahwa "orang mampu mengingat 20 persen dari apa yang dilihat dan 30 persen dari yang didengar. Tetapi orang dapat mengingat 80 persen dari apa yang dilihat dan didengar sekaligus". Penggunaan media video akan membantu anak-anak lebih konsentrasi dan fokus dengan narasi cerita yang akan disampaikan. Tampilan video yang menarik akan menolong anak-anak untuk tidak mudah terdistraksi dengan hal lainnya dan lebih mudah dalam menyerap informasi yang disampaikan.

Berdasarkan permasalahan di atas, dibutuhkan suatu media komunikasi berbasis video untuk melakukan pendekatan Psychological First Aid (PFA), untuk 
menolong anak-anak yang menjadi korban sexual abuse mendapatkan dukungan psikologis segera dalam mengatasi trauma jangka panjang.

\section{LANDASAN TEORI}

\subsection{Child Psychological First Aid (PFA)}

Psychological First Aid (PFA) pertama kali dikembangkan di Amerika oleh National Child Traumatic Stress Network and National Center for PTSD (Brymer et al., 2006). Psychological First Aid (PFA) adalah alat berdasarkan informasi yang dapat dipakai untuk menyediakan dukungan psikologis secara cepat kepada individu atau keluarga setelah bencana, konflik, peristiwa traumatis, atau kejadian darurat lainnya (Susanto, 2019).

Semua orang akan memunculkan reaksi, ketika berada dalam kondisi yang membuatnya stres dan sulit. Saat seseorang mengalami peristiwa yang menakutkan, menyedihkan, dan membuat mereka trauma, akan muncul beberapa reaksi pada tubuh, hati, dan pikirannya. Psychological first aid (PFA) berisi pengetahuan umum tentang reaksi yang muncul, saat seseorang mengalami peristiwa traumatis dan memberikan cara untuk mengatasi reaksi-reaksi tersebut.

PFA tidak harus dilakukan oleh seorang profesional konselor, psikolog atau seorang yang ahli dalam bidang psikologi. Namun PFA bisa dilakukan oleh semua orang, setelah dibekali pengetahuan untuk menolong orang-orang dalam kondisi krisis. PFA seperti obat pertolongan pertama pada kecelakaan (P3K), yang bisa digunakan oleh semua orang untuk menolong orang yang terluka pertama kali sebelum dibawa ke dokter. PFA dapat kita berikan segera, ketika kita mengetahui ada seseorang dalam kondisi yang krisis, kesulitan, terluka dan mengalami peristiwa yang membuatnya trauma.

PFA sangat penting diberikan segera untuk membuat seseorang yang dalam situasi krisis merasa aman, tenang, dan memiliki pengharapan. PFA dapat dipakai untuk membantu seseorang yang mengalami peristiwa traumatis, mengatasi tekanan emosional mereka dengan lebih baik, dan mengurangi dampak negatif dari peristiwa traumatis yang mereka alami.

PFA untuk anak-anak berkontribusi pada pencegahan jangka pendek dan jangka panjang masalah psikologis seperti peristiwa menyedihkan dan traumatis, dengan membina fungsi adaptif dan koping (Terlonge, 2013). Sebagian besar anak-anak selamat dari peristiwa yang menyedihkan tanpa menderita masalah kesehatan mental jangka panjang, dan banyak yang mengalami pemulihan sendiri. Namun, pemulihan yang meningkat dapat terjadi ketika dukungan yang tepat diberikan pada tahap awal, dan risiko masalah kesehatan mental jangka panjang akan berkurang secara drastis.

Pertolongan pertama psikologis (PFA) untuk anak-anak adalah suatu pendekatan untuk mengurangi tekanan awal anak-anak yang disebabkan oleh peristiwa traumatis (Susanto, 2019). Tindakan sexual abuse memberikan dampak trauma pada anak, yang jika tidak segera ditangani akan menimbulkan trauma berkepanjangan (PTSD). Maka dari itu PFA ini bisa dipakai untuk menolong anak mengatasi traumanya.

Ada beberapa alasan penting menerapkan PFA pada anak yang menjadi korban sexual abuse, yaitu mengurangi risiko gangguan mental, meningkatkan self-healing, dan membangun harapan pada anak (Susanto, 2019).

Menurut World Federation of Mental Health (2016), ada tiga prinsip utama dalam PFA yang harus dipahami dan diterapkan saat akan menolong anak-anak dalam situasi krisis, yaitu: 
1. Lihat (Look): Prinsip pertama yang harus kita lakukan adalah look. Kita harus melakukan observasi. Mengecek apakah anak tersebut dalam kondisi yang aman. Kemudian observasi kebutuhan dasar (seperti makanan dan minuman). Dengan kata lain, kita mengecek apakah kebutuhankebutuhan dasar anak sudah terpenuhi sekaligus melakukan observasi reaksi ketidaknyamanan yang serius yang muncul pada anak.

2. Dengarkan (Listen): Prinsip kedua yang harus kita lakukan adalah listen. Kita perlu memulai komunikasi dan membangun relasi dengan anak yang membutuhkan dukungan atau pertolongan. Kita membuat mereka merasa nyaman bercerita dengan kita dan menanyakan apa yang mereka butuhkan atau perlu menjadi perhatian. Setelah itu kita mendengarkan dan membantu mereka untuk merasa tenang, aman dan memiliki harapan.

3. Jaringan (Link): Prinsip ketiga yang harus kita lakukan adalah link. Kita dapat membantu anak untuk menemukan tempat yang dapat memberikan layanan kebutuhan dasar dan akses pelayanan bagi mereka. Ini berarti kita membantu anak menyelesaikan masalahnya, memberikan informasi secara benar, dan menghubungkan anak dengan orang yang dapat memberikan dukungan sosial secara utuh, seperti keluarga, konselor, dan psikolog.

Menurut World Federation of Mental Health (2016), tujuan melakukan PFA adalah sebagai berikut:

1. Memberikan pertolongan pertama psikologis
2. Mengurangi dampak negatif dari pengalaman traumatis

3. Menguatkan fungsi adaptif jangka pendek \& jangka panjang korban

4. Akselerasi proses pemulihan yang mendukung anak dalam krisis mengalami pemulihan yang cepat

Sedangkan manfaat PFA bagi anak-anak yang mengalami peristiwa trauma adalah sebagai berikut:

1. Safety (rasa aman) : memberikan rasa aman pada anak karena ada dukungan psikologis dan sosial yang diberikan kepada mereka.

2. Calming (tenang \& nyaman): menenangkan dan membantu anak untuk stabil kembali dari perasaan sedih dan derita yang dikarenakan peristiwa menakutkan atau traumatis yang dialaminya.

3. Connectedness to others (tidak sendiri, ada dukungan sosial): menolong anak merasa tidak sendirian dalam menghadapi situasi sulitnya, karena mereka terhubung dengan orang-orang yang selalu mau menolong, menguatkan dan mengasihinya .

4. Self efficacy - Empowerment (sikap positif pada diri korban - merasa mampu): PFA akan menolong memberi keyakinan pada anak bahwa akan ada hasil yang positif dalam tindakan yang dilakukan dan juga mampu untuk menolong diri mereka sendiri. Dengan demikian mereka dapat bangkit menghadapi masalah yang mereka hadapi dan berdamai dengan masalahnya.

5. Hopefulness (harapan): PFA akan menolong anak memiliki harapan. Meyakinkan anak bahwa ada harapan untuk kembali pulih. PFA meyakinkan mereka bahwa akan selalu ada orangorang yang peduli, sayang dan ingin untuk membantu mereka untuk pulih.

Terdapat lima elemen dasar yang harus diperhatikan dan dipenuhi dalam menerapkan PFA, yaitu: 
1. Keamanan dan Keselamatan

Memastikan anak terbebas dari kekhawatiran atas peristiwa yang telah terjadi. Setelah itu membantu untuk memenuhi kebutuhan dasar untuknya seperti memberikan informasi untuk mengatasi traumanya Jika korban mengalami luka, kita perlu segera menghubungi pihak medis.

\section{Ketenangan}

Menenangkan dan membantu anak untuk stabil kembali dari perasaan sedih dan derita yang dikarenakan peristiwa menakutkan yang dialaminya. Hal ini dapat melakukan dengan menciptakan suasana yang tenang untuk korban dan menghilangkan semua tanda-tanda bahaya.

\section{Keterhubungan}

Membantu dalam memastikan anak untuk tetap terhubung dengan relasi dekat atau pihak luar yang dapat membantu anak. Hal ini bisa dilakukan dengan menghubungkan anak pada relasi terdekat, seperti keluarga, atau siapapun yang bisa dikatakan sebagai relasi terdekat untuk tetap bersama menemani anak dalam masa-masa sulitnya.

\section{Efikasi Diri}

Meyakinkan anak bahwa akan ada hasil yang positif dalam tindakan yang dilakukan dan juga mampu untuk menolong diri sendiri. Dalam menguatkan efikasi korban perlu melibatkan dirinya sendiri secara langsung untuk mengetahui dan menemukan kebutuhanya sendiri.

\section{Harapan}

Menyampaikan pada anak bahwa ada harapan untuk kembali pulih dan ada orang-orang yang ingin untuk membantunya. Meyakinkan mereka bahwa ketakutan yang dirasakannya adalah hal yang normal.

\subsection{Teori Child Development}

\section{Perkembangan Spiritual Anak}

Menurut John Westerhoff (1976), ada empat tahap perkembangan spiritual anak yaitu experienced faith, affiliative faith, searching faith dan owned faith. Anak usia 10-12 tahun (masa kanak-kanak), masuk dalam tahap experienced faith. Pada tahap ini, pengalaman bersama orang-orang yang dikasihi memiliki pengaruh besar terhadap iman dan kehidupan akan anak-anak untuk mengenal Tuhan. Fondasi iman anak-anak dibentuk dalam pengalaman saat mereka belajar mempercayai orang lain, diri sendiri, dan dunia sekitar. Tindakan orang-orang di dekat anak akan mempengaruhi persepsi mereka.

Tindakan itu akan membingkai apa yang akan dialami anak-anak. Ketika anak-anak menjadi bagian dalam komunitas yang tepat maka kebutuhan untuk dikasihi, diinginkan dan diterima akan terpenuhi. Pengalaman dikasihi itulah yang akan menolong anakanak bertumbuh mengenal Tuhan.

Pada anak usia 10-12 tahun, anak memasuki tahap Mythic-Literal Faith dalam perkembangan spiritual yang dibuat oleh James Fowler. Di tahap ini, anak mampu menangkap makna kehidupan dan nilai-nilai kebenaran melalui narasi dan cerita. Nilainilai kebenaran Firman Tuhan yang dikemas dalam narasi dan cerita akan sangat mudah ditangkap oleh anak usia 10-12 tahun. Hal ini karena anak memiliki pemikiran operasional yang konkret, sudah mengembangkan kemampuan berpikir secara logis dan dapat memilah hal yang nyata dari khayalan dan begitupun sebaliknya (Fowler, 1991).

Pada usia 10-12 tahun adalah masa paling tepat untuk anak-anak dapat berjumpa dengan Tuhan lewat berbagai pergumulan yang mereka hadapi. Hal ini terjadi karena di masa ini anak-anak banyak bergumul mengenai pilihan-pilihan hidup yang beragam. Ini berarti mereka perlu ditolong untuk memilih keputusan dan pilihan hidup yang benar, mulai dari hal kecil sampai halhal besar yang dapat mempengaruhi 
kehidupan mereka.

Pada usia ini, anak akan tahu siapa diri mereka sebagaimana mereka masuk dalam cerita narasi Allah, dan pilihan-pilihan hidup apa yang menjadi tanggung jawab mereka sehingga pada akhirnya melalui pergumulan yang mereka hadapi, anak-anak semakin bertumbuh dalam relasi dengan Tuhan (Primasanti, 2019).

Anak-anak yang menjadi korban sexual abuse pada usia 10-12 tahun, perlu ditolong dan diarahkan untuk menemukan Tuhan lewat berbagai pengalaman yang menyakitkan bagi dirinya. Kita dapat menolong mereka dengan mempersiapkan hati mereka terlebih dahulu, sehingga hati mereka siap untuk menerima kebenaran Firman Tuhan seperti tanah yang baik yang ditaburi kebenaran Firman Tuhan akan tumbuh dan menghasilkan buah yang berlimpahlimpah.

\section{Perkembangan Kognitif Anak}

Menurut teori perkembangan kognitif (cognitive theory) Piaget, anak-anak usia 10-12 tahun masuk dalam tahap operasional konkret. Dalam tahap ini anak sudah bisa berpikir secara rasional dan berpikir logis mengenai kejadian-kejadian konkret. Kemampuan anak dalam mempelajari konsep meningkat, contohnya kemampuan verbal, membaca, dan matematika juga meningkat. Mereka bisa mengelompokkan suatu hal dari umum menjadi spesifik dan sebaliknya. Kemampuan berpikir secara logis dan mengingat juga meningkat. (Soetjiningsih \& Gde Ranuh, 2016).

Ciri khas anak pada tahap ini adalah proses berpikir yang lebih logis, mulai menguasai bacaan-bacaan fundamental, menulis, keterampilan dan pengetahuan akademik lainnya.
Dengan demikian pada tahap ini, anak-anak sudah bisa memfungsikan akalnya untuk berpikir logis terhadap sesuatu yang bersifat nyata. Pada tahapan ini, pemikiran logis menggantikan pemikiran intuitif (naluri) dengan syarat pemikiran tersebut dapat diaplikasikan menjadi contoh-contoh yang nyata atau spesifik bagi anak. Anak hanya dapat memecahkan suatu masalah ketika objek dari masalah tersebut bersifat empirik (nyata) atau ditangkap oleh panca indra mereka, bukan yang bersifat khayal (Bujuri, 2018).

\section{Perkembangan Seks Anak}

Dalam Nugraha dan Sonia (2016, p. 23) dikemukakan lima fase tahapan perkembangan seks yaitu : fase oral (0-2 tahun), fase anal (2-3 tahun), fase falik (3-6 tahun), fase laten (6-12 tahun), dan fase genital (12 tahun keatas). Tahapan perkembangan seks ini dikemukakan oleh seorang ahli psikoanalisa yaitu Sigmund Freud.

Anak usia 10-12 tahun masuk dalam fase laten. Pada fase ini anak mengalami aktivitas seksual yang mulai berkurang dikarenakan anak sedang fokus pada perkembangan fisik dan kognitifnya. Sehingga anak-anak pada usia ini belum sadar jika mengalami sexual abuse yang pada akhirnya mengakibatkan mereka mengalami PTSD (post-traumatic stress disorder). Gejala PTSD dapat muncul pada anak yang menjadi korban sexual abuse beberapa tahun kemudian setelah mengalami pengalaman traumatis, karena anak tidak mengerti kondisi yang dialaminya.

Ketika anak-anak mengalami peristiwa traumatis tetapi saat itu mereka tidak dapat memahaminya, mereka akan menggunakan berbagai cara dan berupaya menyembunyikannya. Hal ini akan semakin memperburuk kondisi anak, jika tidak segera ditangani. Bagi anak-anak ini, mereka akan senang menghabiskan waktu dalam dunia khayalan karena bagi mereka berkhayal dapat mengobati rasa sakit luka emosionalnya yang parah. Namun cara ini 
juga dapat menciptakan kebingungan psikologis dalam diri anak, ketika dunia khayalan seakan lebih nyata dari dunia nyata itu sendiri (Yantzi, 2009).

\subsection{Child Sexual Abuse}

Sexual abuse (kekerasan seksual) pada anak dapat didefinisikan sebagai suatu bentuk penyiksaan pada anak yang dilakukan orang dewasa atau remaja, dengan menggunakan anak untuk rangsangan seksual. Bentuk sexual abuse pada anak dapat berupa meminta atau memaksa anak untuk melakukan aktivitas seksual, memberikan paparan yang tidak senonoh dari alat kelamin untuk anak, menampilkan pornografi pada anak, melakukan hubungan seksual dengan anak, melihat ataupun melakukan kontak fisik dengan kelamin anak (kecuali pemeriksaan medis) atau menggunakan anak untuk memproduksi pornografi anak (Wahyuni, 2016).

\section{Kategori Child Sexual Abuse}

Dalam Nurwati, N., \& Krisnani, H (2019) dijelaskan bahwa, sexual abuse dibagi menjadi 2 kategori, yaitu:

\section{Familial Abuse (incest)}

Familial abuse adalah sexual abuse yang dilakukan oleh orang yang masih memiliki hubungan darah atau merupakan bagian dari keluarga inti seperti orangtua pengganti, kakek, nenek, atau saudara. Sexual abuse pada anak dalam keluarga, dapat berbentuk seperti penganiayaan yang melibatkan perbuatan untuk dapat menstimulasi pelaku secara seksual. Bentuk yang kedua ialah pemerkosaan yang berupa oral dan juga hubungan dengan alat kelamin. Bentuk yang terakhir berupa sexual abuse yang paling fatal dikarenakan pemerkosaan secara paksa meliputi kontak seksual pada anak.

\section{Extra-familial Abuse}

Extra-familial sexual abuse adalah kekerasan seksual yang dilakukan oleh orang di luar lingkungan keluarga. Pelaku dari kategori ini merupakan orang dewasa yang cukup dekat dan dikenal dengan anak serta telah dibangun relasi antara pelaku dan anak. Contohnya seperti guru, sopir, pengasuh, atau petugas sekolah.

\section{Dampak Child Sexual Abuse}

Dalam American Journal of orthopsychiatry yang ditulis oleh Finkelhor, D., \& Browne, A (1985), dijelaskan bahwa ada 4 jenis dampak traumatis yang dialami anak-anak korban sexual abuse :

\section{Pengkhianatan (Betrayal)}

Kepercayaan merupakan dasar utama bagi korban sexual abuse. Seorang anak tentunya mempunyai kepercayaan yang sangat besar kepada kedua orangtuanya dan kepercayaan itu dimengerti dan dipahami. Dengan adanya kekerasan yang menimpa dirinya dan berasal dari orangtuanya sendiri membuat seorang anak merasa dikhianati. Mereka mengalami depresi karena kehilangan figur yang dapat dipercaya. Anak-anak yang menjadi korban mengalami kekecewaan yang sangat parah. Perilaku antisosial dan kenakalan pada korban merupakan ekspresi dari kemarahan atas pengkhianatan yang mereka alami. Bentuk kemarahan pada anak merupakan cara untuk melindungi dirinya dari pengkhianatan yang akan terjadi di masa depan.

2. Trauma secara seksual (Traumatic sexualization)

Russel (Tower, 2002) menemukan bahwa perempuan yang mengalami sexual abuse cenderung menolak hubungan seksual, dan sebagai konsekuensinya menjadi korban sexual abuse dalam rumah tangga. Finkelhor mencatat bahwa anak-anak yang korban, saat dewasa mereka lebih memilih untuk memiliki pasangan sesama jenis karena menganggap laki-laki tidak dapat dipercaya.

3. Merasa tidak berdaya (Powerlessness) 
Rasa tidak berdaya muncul karena adanya rasa takut dan kekecewaan di kehidupan korban. Mimpi buruk, fobia, kewaspadaan berlebihan dan kecemasan dialami oleh korban disertai dengan rasa sakit. Perasaan tidak berdaya mengakibatkan individu merasa lemah dan merasa kurang efektif dalam mengatasi masalah. Ini tercermin dalam kehidupan korban seperti ada masalah belajar, suka melarikan diri, dan kesulitan mengerjakan sesuatu. Resiko tertinggi pada korban adalah jika terjadi kembali tindakan sexual abuse pada anak yang menjadi korban, maka mereka sering merasa tidak berdaya untuk menggagalkan orang lain yang mencoba memanipulasi atau menyakiti mereka.

\section{Stigmatization}

Sexual abuse pada anak dapat menyebabkan anak mengalami rasa bersalah, malu, dan gambar diri yang buruk. Rasa bersalah dan malu pada anak terbentuk akibat ketidakberdayaan dan perasaan bahwa mereka tidak memiliki kekuatan untuk mengontrol dirinya. Stigmatisasi juga menghasilkan perasaan berbeda berdasarkan keyakinan yang salah pada anak, anak korban sexual abuse berpikir bahwa tidak ada orang lain yang pernah mengalami pengalaman seperti itu dan orang lain akan menolak orang yang mengalaminya.

Dampak lain yang terjadi pada anak yang menjadi korban sexual abuse, yaitu terlibat dalam penyalahgunaan narkoba atau alkohol, aktivitas kriminal, atau prostitusi untuk menghukum tubuhnya dan berusaha untuk berusaha menghindari memori tentang kejadian kekerasan yang pernah menimpa dirinya.

\subsection{Trauma Pada Anak Korban Sexual Abuse}

Trauma terjadi karena beberapa peristiwa menyedihkan yang begitu ekstrem atau intens sehingga membanjiri kemampuan seseorang untuk mengatasinya, yang mengakibatkan dampak negatif yang bertahan lama. Peristiwa sexual abuse pada anak-anak juga dapat menyebabkan trauma berkepanjangan. Mengalami peristiwa traumatis di masa kanak-kanak dapat memiliki konsekuensi yang sangat menghancurkan. Jika dikaitkan dengan adaptasi dalam struktur dan fungsi otak akan berdampak pada perkembangan kognitif, emosional dan sosial anak. Trauma masa kanak-kanak dikaitkan dengan peningkatan risiko masalah kesehatan mental di kemudian hari, kesulitan dalam hubungan pribadi dan sosial, serta peningkatan risiko pengalaman stres baru, termasuk sexual abuse berulang (McCrory, Gerin, \& Viding, 2017).

Gambar 1. Peningkatan Resiko Trauma pada Anak Korban Sexual Abuse

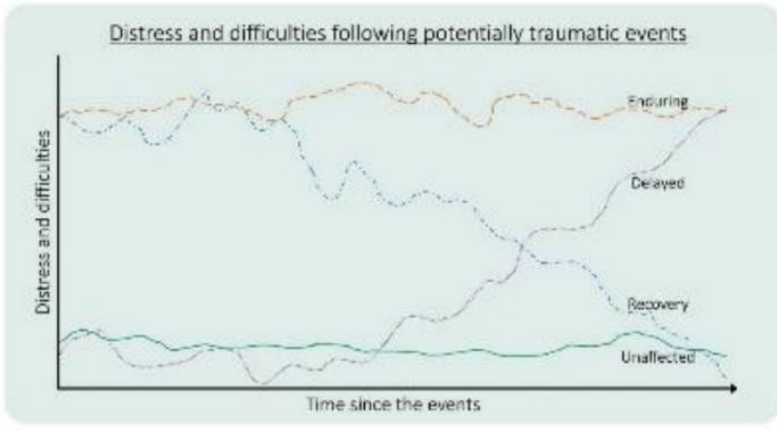

Sumber: https://uktraumacouncil.org/

Setelah mengalami peristiwa yang sangat menyedihkan, banyak anak pada awalnya akan mengalami tingkat kesusahan yang tinggi dan merasa sulit untuk melanjutkan kehidupan normal mereka. Sebagian kecil anak-anak dan remaja pada awalnya mungkin mengalami reaksi yang sangat sedikit bahkan terhadap peristiwa yang ekstrim. Namun dalam jangka waktu yang lebih lama, beberapa dari anak-anak yang tampaknya tidak terpengaruh itu mengalami berbagai kesulitan. Pada grafik di atas, ada empat jalur lintasan berbeda yang telah diidentifikasi - bertahan, pulih, tidak 
terpengaruh dan tertunda. Jenis kesusahan dan kesulitan sebenarnya yang mungkin dialami anak-anak setelah peristiwa traumatis dapat sangat bervariasi (Bonanno, 2004).

Peristiwa sexual abuse yang dialami anak-anak menimbulkan trauma yang kompleks. Paparan trauma kompleks dapat berdampak pada perkembangan emosional, psikologis, sosial dan fisik anak. Namun, tidak berarti semua anak terpengaruh dengan cara yang sama . Beberapa mungkin menunjukkan reaksi yang terbatas atau tidak merugikan sama sekali, untuk yang lain dampaknya tertunda, dan untuk yang lain masih dampaknya langsung dan parah. Perbedaan ini dapat diakibatkan sebagian karena faktor genetik, biologis, psikologis dan sosial serta karena perbedaan sifat trauma itu sendiri . Pengalaman anak terhadap suatu peristiwa berbeda dari tanggapan mereka terhadap peristiwa tersebut .

Pengalaman trauma kompleks dapat memengaruhi berbagai aspek perkembangan anak. Perubahan telah didokumentasikan di tingkat biologis, misalnya dalam kaitannya dengan struktur dan fungsi otak, tingkat kortisol, dan tingkat peradangan. Ada juga dampak pada fungsi psikologis dan emosional. Misalnya, mungkin ada perubahan dalam cara seorang anak mengidentifikasi, menanggapi, dan mengatur emosi mereka. Demikian pula, bisa ada dampak pada bagaimana seorang anak mengembangkan rasa diri, harga diri, dan perasaan orang lain - terutama dalam kaitannya dengan kepercayaan. Ada bukti kuat yang menunjukkan peningkatan risiko gangguan kesehatan mental termasuk misalnya, kecemasan, depresi, gangguan stres pasca-trauma kompleks (PTSD), dan gangguan perilaku.

Anak-anak juga dapat hadir dengan berbagai respons pada tingkat perilaku, seperti peningkatan risiko melukai diri sendiri, bunuh diri, dan pencapaian pendidikan yang lebih rendah . Mengingat efek ini, mungkin tidak mengherankan bahwa terdapat dampak yang signifikan pada fungsi sosial anak, dengan peningkatan kesulitan yang sering diamati dalam hubungan mereka dengan teman sebaya dan orang dewasa. Terakhir, ada juga bukti dampaknya pada kesehatan fisik. Mekanisme di mana trauma kompleks mempengaruhi kesehatan mental dan fisik dapat bervariasi tergantung pada metode penilaian yang digunakan untuk trauma kompleks.

\section{Indikator Fisik dan Perilaku Sexual Abuse Terhadap Anak}

Indikator ini berguna untuk mengetahui tandatanda pada anak yang terlibat pada sexual abuse (WHO, 2003) :

\begin{tabular}{|l|}
\hline \multicolumn{1}{|c|}{ INDIKATOR FISIK } \\
\hline $\begin{array}{l}\text { 1. Cedera genital yang tidak dapat } \\
\text { dijelaskan. }\end{array}$ \\
\hline 2. Vulvovaginitis berulang. \\
\hline 3. Keputihan dari vagina atau penis. \\
\hline $\begin{array}{l}\text { 4. Mengompol dan BAB melebihi } \\
\text { usia biasanya. }\end{array}$ \\
\hline $\begin{array}{l}\text { 5. Keluhan anal (misalnya fisura, } \\
\text { nyeri, perdarahan) nyeri saat buang } \\
\text { air kecil. }\end{array}$ \\
\hline 6. Infeksi saluran kemih. \\
\hline 7. Kehamilan. \\
\hline 8. STI (sexually transmitted \\
infections) - mengalami penyakit \\
seksual menular seperti HIV. \\
\hline
\end{tabular}

Tabel 1 Indikator Fisik pada Anak Korban Sexual Abuse 


\section{INDIKATOR PERILAKU \\ 1. Regresi dalam perilaku, kinerja sekolah atau pencapaian tonggak perkembangan.}

2. Respon traumatis akut seperti perilaku melekat dan mudah tersinggung pada anak kecil.

3. Gangguan tidur dan gangguan makan.

4. Sangat dekat dengan orang yang jauh lebih tua. Menceritakan tentang teman baru atau tidak tergabung dalam lingkungan temantemannya.

5. Masalah di sekolah (sering bolos sekolah/kegiatan lainnya, menghilang untuk kurun waktu yang lama atau kelihatan sangat letih di sekolah) dan masalah sosial.

6. Perubahan mood (hiperaktif, diam, bermusuhan, agresif, mudah marah, cemas, menarik diri, dan depresi).

7. Harga diri yang buruk.

8. Perilaku seksual yang tidak pantas.

9. Penggunaan bahasa yang tidak wajar (kata-kata kasar, dewasa, seksual) atau cara berbicara yang tidak baru.

Tabel 2 Indikator Perilaku pada Anak Korban Sexual Abuse

\subsection{Hasil Wawancara Konselor Anak}

Penulis melakukan wawancara dengan dua orang konselor anak yang banyak memberikan konseling dan melayani anak-anak yang menjadi korban sexual abuse. Sebelum mengambil data dari wawancara dengan dua konselor ini. Penulis telah menghubungi banyak psikolog dan konselor anak untuk melakukan wawancara juga. Fakta unik yang penulis temukan selama proses pencarian data dari berbagai konselor atau psikolog anak adalah kebanyakan dari mereka tidak pernah melayani anak korban kekerasan seksual secara langsung saat hal itu terjadi. Namun mereka kebanyakan menolong saat korban sudah dewasa. Korban mengalami sexual abuse saat kecil, tetapi baru sadar dan berani bercerita ketika beranjak dewasa.

Pertolongan pertama pada korban sexual abuse sangatlah penting. Melalui wawancara dengan beberapa konselor anak, mereka menyarakan akan jauh lebih baik, jika korban langsung mendapat pertolongan pertama psikologis (PFA) saat mengalami sexual abuse. Jika baru diketahui saat dewasa, masalah akan lebih kompleks, penanganan lebih rumit dan butuh proses pemulihan yang sangat panjang. Luka pengalaman sexual abuse yang terus disimpan dan tak pernah diceritakan akan semakin parah, jika tak segera diobati.

Dari wawancara yang penulis lakukan dengan Kartika Bayu Primasanti dan Melati Tan, penulis menemukan bahwa sexual abuse pada anak adalah masalah yang serius dan kompleks. Kekerasan seksual adalah hal berat yang dialami anak sehingga perlu waktu lama untuk proses pemulihannya, apalagi jika anak tidak langsung mendapat pertolongan (Tan, 2020). Hal ini senada dengan yang diungkapkan oleh Primasanti bahwa trauma seksual bisa berkepanjangan dan sangat kompleks. Pertolongan pertama memberikan kesempatan anak mengurangi dampak negatif dari luka yang berkepanjangan tersebut. Konseling pun tidak bisa menyembuhkan tetapi mengurangi resiko luka semakin besar ke depan. Beliau juga menekankan bahwa setiap proses konseling itu tidak menyembuhkan, tetapi memulihkan (Primasanti, 2020).

Dampak kekerasan seksual dalam diri anak sangat kompleks. Dampaknya mencakup ke 
emosi, perilaku, menghantam harga diri anak, low self esteem, tidak percaya diri, sosial, rasa takut terhadap orang dan kehilangan rasa aman (Tan, 2020). Dampak yang kelihatan dari salah satu anak korban sexual abuse yang dilayani oleh Primasanti adalah anak selalu mencari pemenuhan, memiliki kebutuhan seksual yg tinggi sekali, mengalami kerusakan gambar diri, self esteem yang sulit menerima keberhargaan dirinya, dan tidak bisa fokus pada hal lain. Selain itu, dua narasumber juga menekankan sexual abuse menyebabkan trauma yang berkepanjangan, jika tidak segera ditangani.

Indikator dan ciri-ciri umum anak yang mengalami sexual abuse antara lain, korban sering marah tanpa terkendali pada kondisi tertentu, korban menarik diri dari lingkungan perhatian, mencari perhatian lawan jenis, menggunakan pakaian yang ekstrim (tertutup semua atau terbuka semua), korban menghindari pergaulan dengan lawan jenis, menunjukkan histeria ketika berinteraksi dengan lingkungan atau orang yang mengingatkan korban pada traumanya.

Psychological First Aid (PFA) pada anak korban kekerasan seksual sangat penting. Pertolongan pertama memberikan kesempatan anak mengurangi dampak negatif dari luka dan trauma yang berkepanjangan.

Hal-hal penting saat memberikan pertolongan pertama pada anak yang menjadi korban kekerasan seksual adalah memberikan ruang aman kepada anak, menunggu hingga anak siap untuk bercerita, menjaga bondary secara fisik, menjelaskan pada anak tentang keberhargaan diri, tidak mengekspos anak dengan pertanyaan, fakta atau kondisi yang mengingatkannya pada luka masa lalu tanpa kesiapan. Hal penting juga yang perlu kita lakukan adalah respon kepada anak korban kekerasan seksual. Ketika anak berani bercerita kita harus percaya. Jika kita tidak percaya, hal itu akan sangat memukul dirinya dan menjadi sebuah penolakan hebat bagi dirinya. Setelah anak bercerita, kita merefleksikan dan mengkonfirmasi dan memberikan afirmasi. Kita menggali lebih jauh perasaannya dulu, seperti apa yang dia pikirkan, apa yang dia rasakan, apa yang sudah dia lakukan dan apa yang akan dia lakukan.

Video psikoedukasi menjadi salah satu alat untuk memberikan pertolongan pertama bagi anak korban kekerasan seksual. Video bisa memberitahu anak untuk mencari pertolongan pada siapa saat mereka tidak tahu. Video ini juga bisa mengedukasi anak tentang kekerasan seksual sama sekali bukan kesalahannya. Kekerasan seksual telah membuat banyak anak yang menjadi korban merasa bahwa kekerasan seksual adalah kesalahannya sehingga muncul perasaan menyalahkan diri sendiri dan takut. Penanganan kasus sexual abuse sangat kompleks dan memerlukan proses panjang. Setiap anak yang menjadi korban sexual abuse memiliki karakter dan kepribadian yang unik. Ada beberapa anak yang pemulihannya sangat cepat dan juga lama. Namun dari pengalaman kedua narasumber, ketika anak sudah berani bercerita, maka ia akan lebih cepat pulih, sebagaimana halnya luka yang segera dibalut, akan lebih cepat pulih. Sebaliknya jika luka sexual abuse itu dibiarkan, disimpan, dan disembunyikan maka pemulihannya juga membutuhkan waktu yang lebih lama. Seperti luka yang tak segera ditangani menimbulkan nanah, borok, tumor sampai kanker, maka luka sexual abuse akan menimbulkan dampak yang lebih parah jika tidak segera ditolong.

\section{METODE PERANCANGAN Metode Pengumpulan Data}

Data Primer

1. Wawancara

Wawancara adalah salah satu metode pengumpulan data untuk mendukung perancangan video pyschological first aid 
bagi anak korban sexual abuse. Wawancara dilakukan secara langsung kepada konselor dan psikolog anak yang pernah menangani kasus kekerasan seksual pada anak.

Data Sekunder

\section{Studi Literatur}

Metode ini dilakukan dengan cara mengkaji informasi media cetak maupun media online seperti koran, buku, jurnal, dan artikel yang fokus pada topik Child Pyschological First Aid dan Child Sexual Abuse sebagai informasi pendukung.

\section{METODE ANALISIS DATA}

Analisis data menggunakan metode $5 \mathrm{~W}+1 \mathrm{H}$ (What, Who, Why, When, Where, dan How). Berikut hasil analisis menggunakan metode $5 \mathrm{~W}+1 \mathrm{H}$ :

1. What: Permasalahan yang terjadi adalah tingginya angka kasus sexual abuse pada anak. Kasus sexual abuse pada anak dapat menimbulkan trauma jangka panjang, jika anak tidak segera mendapatkan pertolongan pertama. Maka penerapan PFA untuk anak-anak korban sexual abuse sangatlah penting.

2. Who: Target sasaran utama (primer) video adalah anak-anak usia 10-12 tahun yang menjadi korban sexual abuse. Sedangkan target sasaran sekundernya adalah guru, konselor, psikolog dan pemerhati anak.

3. Why: Video ini penting karena memberikan dukungan psikologis pertama bagi anak-anak korban sexual abuse sehingga anak dapat tertolong. Penerapan PFA dikemas dalam bentuk video animasi 2D menjadi salah satu alternatif karena masih sedikit yang menggunakan media digital. Media sebelumnya kebanyakan masih menggunakan media cetak seperti modul untuk menolong anak-anak korban sexual abuse. Penggunaan media video akan membantu anak-anak lebih konsentrasi dan fokus dengan narasi cerita yang akan disampaikan. Tampilan video yang menarik akan menolong anak-anak untuk tidak mudah terdistraksi dengan hal lainnya dan lebih mudah dalam menyerap informasi yang disampaikan.

4. When: Perancangan video ini direalisasikan pada awal bulan Oktober tahun 2020.

5. Where: Video ini telah dipublikasikan di youtube. Setelah itu link youtube akan diberikan kepada guru-guru. konselor/psikolog anak dan pemerhati anak, supaya dapat dipakai menjadi salah satu alat dalam menolong anak yang menjadi korban sexual abuse.

6. How: Dalam video 1, anak-anak korban sexual abuse harus didampingi oleh orang dewasa yang berkomitmen serius mau membantu mereka. Orang dewasa inilah yang akan menjelaskan pada mereka jika ada sesuatu yang mereka belum mengerti dan menghubungkan mereka dengan konselor/psikolog anak untuk mendapat bantuan lebih lanjut.

Sedangkan dalam video 2, video ini dirancang khusus untuk mengedukasi guruguru dan pemerhati anak sadar akan kondisi Indonesia darurat sexual abuse pada anak. Guru-guru bisa menontonnya dan membagikan link youtube sehingga terbentuk komunitas yang tahu penanganan pertama pada anak korban sexual abuse.

\section{Konsep Perancangan}

\section{Konsep Perancangan Video 1}

1. Format Program: Sebuah video mengenai penerapan PFA untuk memberikan dukungan psikologis pertama dalam mengatasi trauma yang dialami anak korban sexual abuse. Dengan output video yang dihasilkan adalah MP4 dengan ratio 16:9.

2. Judul Program: Faith \& Grace.

3. Durasi: 9 menit. 
4. Tujuan Program: Video animasi 2D Faith \& Grace ini ditujukan untuk memberikan dukungan psikologis pertama pada anak yang menjadi korban sexual abuse dalam mengatasi traumanya. Video telah dipublikasikan secara umum dengan cara diupload melalui internet ke website penyedia layanan video streaming seperti youtube dan dibagikan kepada guru Kristen, konselor maupun guru BK di sekolahsekolah untuk menolong anakanak yang menjadi korban sexual abuse.

5.Pesan yang ingin disampaikan: memberikan informasi pada anak untuk mengatasi traumanya dan menghubungkan (link) anak pada konselor/psikolog untuk ditindaklanjuti. Video ini juga menyampaikan nilai-nilai kebenaran Firman Tuhan dengan fokus pada pengharapan yang terdapat dalam Kristus.

6. Target Sasaran

a. Demografis

- Usia : 10-12 tahun

- Jenis kelamin : Laki-laki dan perempuan

- Pendidikan : Sekolah Dasar kelas 4-6

- Kelas sosial : Semua kalangan

b. Geografis

- Kota Surabaya (khusus)

- Kota-kota besar di Indonesia (umum)

c. Psikografis : Anak yang menjadi korban sexual abuse

d. Behaviour : Pendiam, tidak berani untuk mengungkapkan peristiwa traumatisnya, gelisah, dan mengalami gejala stres.

e. Cara mencapai target audience : Menghubungi beberapa sekolah mitra dan ministry untuk dapat mengujicobakan produk tugas akhir kepada anak-anak usia 10-
12 tahun yang pernah mengalami sexual abuse.

\section{Konsep Perancangan Video 2}

1. Format Program: sebuah video edukasi untuk guru-guru Kristen mengenai bahaya sexual abuse pada anak. Dengan output video yang dihasilkan adalah MP4 dengan ratio 16:9.

2. Judul Program: Darurat Kekerasan Seksual Pada Anak.

3. Durasi: 4 menit.

4. Tujuan Program: Video animasi 2D Darurat Kekerasan Seksual Pada Anak ini ditujukan untuk guru-guru Kristen ikut bergerak bersama menjadi agenagen pemulihan bagi anak-anak yang menjadi korban sexual abuse. Video telah dipublikasikan secara umum dengan cara diupload melalui internet ke website penyedia layanan video streaming seperti youtube dan dibagikan kepada guru Kristen, konselor maupun guru BK di sekolah-sekolah melalui alumni-alumni FKIP UK Petra untuk dibagikan pada rekan-rekan guru.

5. Pesan yang Ingin Disampaikan: menyadarkan guru-guru Kristen terkait banyaknya kasus sexual abuse pada anak yang terjadi di Indonesia dan dampaknya pada anak-anak. Lalu mengajak guruguru Kristen untuk bergerak bersama menjadi agen-agen pemulihan untuk menolong dan menghadirkan kasih Tuhan Yesus bagi anak-anak yang menjadi korban sexual abuse.

\section{Target Sasaran}

a. Demografis

- Pekerjaan : Guru

- Agama : Kristen

- Jenis Kelamin : Laki-laki dan perempuan

b. Geografis

- Kota Surabaya (khusus)

- Seluruh daerah-daerah di Indonesia yang memiliki tingkat kasus sexual abuse pada anak yang tinggi

c. Cara mendapat target audience : Membagikan link video pada alumnialumni FKIP UK Petra yang bekerja di sekolah-sekolah mitra di berbagai daerah, 
untuk disebarkan kepada rekanrekan guru disana.

6. Perancangan

\section{Pra Produksi}

Storyline video Faith dan Grace.

Scene 1 : Perkenalan Faith dan Grace

Faith dan Grace melambaikan tangan dan menyapa anak-anak yang menonton video ini.

Scene 2 : Tuhan menciptakan lakilaki dan perempuan serupa denganNya

Tuhan Yesus yang memeluk Faith dan Grace

Scene 3 : Bagian-bagian tubuh pribadi yang perlu kita jaga

Ditampilkan bagian-bagian tubuh pribadi yang tidak boleh disentuh orang lain seperti mulut, dada, alat kelamin, dan pantat

Scene 4 : Sentuhan yang nyaman dan tidak nyaman

Terjadi tindakan kekerasan seksual yang pelakunya digambarkan dengan bayangan hitam di depan toilet sekolah

Scene 5 : Gambar diri yang rusak dan hancur karena kekerasan seksual

Gambar album yang terbuka, kemudian ada foto Grace dan Faith yang awalnya tersenyum kemudian perlahan berubah menjadi murung dan foto tersebut perlahan sobek menjadi 2 bagian

Scene 6 : Perasaan yang muncul saat sexual abuse terjadi

Digambarkan pengalaman yang dialami Grace dan Faith dan perasaan-perasaan yang muncul pada mereka setelah mengalami kekerasan seksual. Mereka menangis, insomnia, resah, takut, menyalahkan diri sendiri, dan marah. Tetapi dalam semua kondisi yang mereka hadapi ada Tuhan Yesus yang setia menemani dan memeluk mereka.

Scene 7 : Bercerita menjadi awal pemulihan

Grace datang kepada konselor, konselor duduk di samping Grace,
Grace mulai bercerita dan konselor memeluk Grace. Dengan bercerita kepada orang dewasa yang dapat kita percaya seperti orang tua, guru, konselor atau psikolog anak, kita akan dibantu untuk mengalami pemulihan

Scene $8: 3$ cara mencegah kekerasan seksual terulang lagi

Muncul 3 poin utama pencegahan kekerasan seksual yaitu berteriak, lari dan bercerita.

Scene 9 : Ada banyak orang yang peduli denganmu dan siap menolongmu. Ceritakanlah kisahmu untuk mengalami proses pemulihan

Satu persatu datang memeluk Grace dan Faith, mulai dari orangtua, lalu guru-guru Kristen, dan konselor

Scene 10: Kalimat koping untuk membuat anak berani bercerita

Muncul tulisan "Telling a trusted adult or disclosing abuse can help make it stop and start the healing".

Scene 11 : Menghubungkan anak pada layanan konseling melalui konselor/psikolog anak

Ditampilkan foto, nama lengkap, nama panggilan dan nomor HP konselor.

\section{Storyline video "Darurat Kekerasan Seksual"'.}

Scene 1 : Menyapa rekan guru, konselor, dan orangtua yang menonton video ini Scene 2 : Menampilkan data kekerasan seksual pada anak

Scene 3: Data banyaknya anak-anak yang tidak berani menceritakan pengalaman kekerasan seksual yang mereka alami

Scene 4 : Penjelasan dampak serius pada anak-anak yang menjadi korban kekerasan seksual

Scene 5 : Ajakan untuk ikut ambil bagian mengatasi kekerasan seksual pada anak

Scene 6: Cara mencegah kekerasan seksual pada anak

Muncul pertanyaan “Apa yang bisa kita lakukan untuk mencegah dan melindungi anak-anak Indonesia dari kekerasan seksual?'

Scene 7 :Mengambil tindakan pertama untuk menolong anak-anak korban kekerasan seksual 
Aletheia Christian Educators Journal, Vol. 2, No. 1, April 2021, 105-124

$\begin{array}{llr}\text { Segera lakukan tindakan untuk } \\ \text { menolong anak } & \text { seperti } \\ \text { menghubungkan anak } & \text { dengan }\end{array}$
seorang yang dapat memberikan dukungan sosial secara utuh seperti keluarga, konselor dan psikolog anak.

Scene 8 : Menjadi Agent of Healing untuk menyelamatkan anak-anak dari bahaya kekerasan seksual.

\section{Produksi}

Produksi video dilakukan oleh orang yang ahli dalam pembuatan video animasi.

\section{Biaya Produksi}

Dalam pembuatan video ini dibutuhkan biaya Rp. 1.000 .000 untuk membayar orang yang mengerjakannya.

Pasca Produksi

Video yang telah dibuat dipublikasikan melalui youtube, supaya lebih mudah di akses dan dapat menjangkau banyak guru-guru Kristen di seluruh Indonesia.

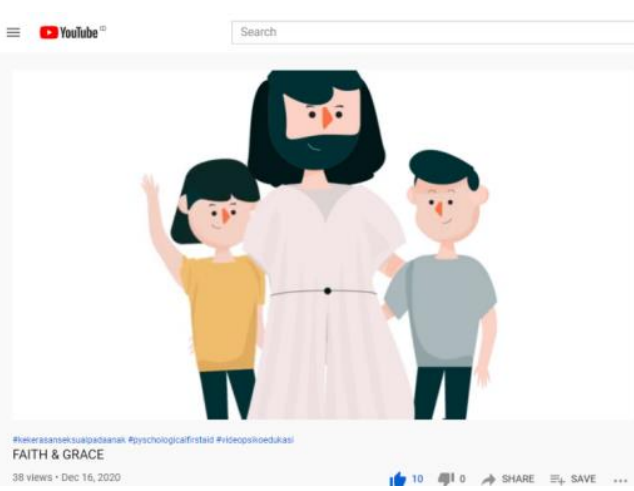

Gambar 2. Publikasi Video Faith dan Grace

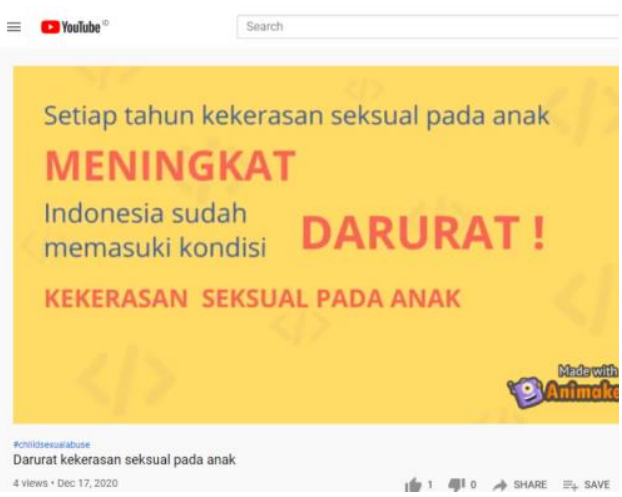

Gambar 3. Publikasi Video Darurat Kekerasan Seksual

\section{Hasil Final}
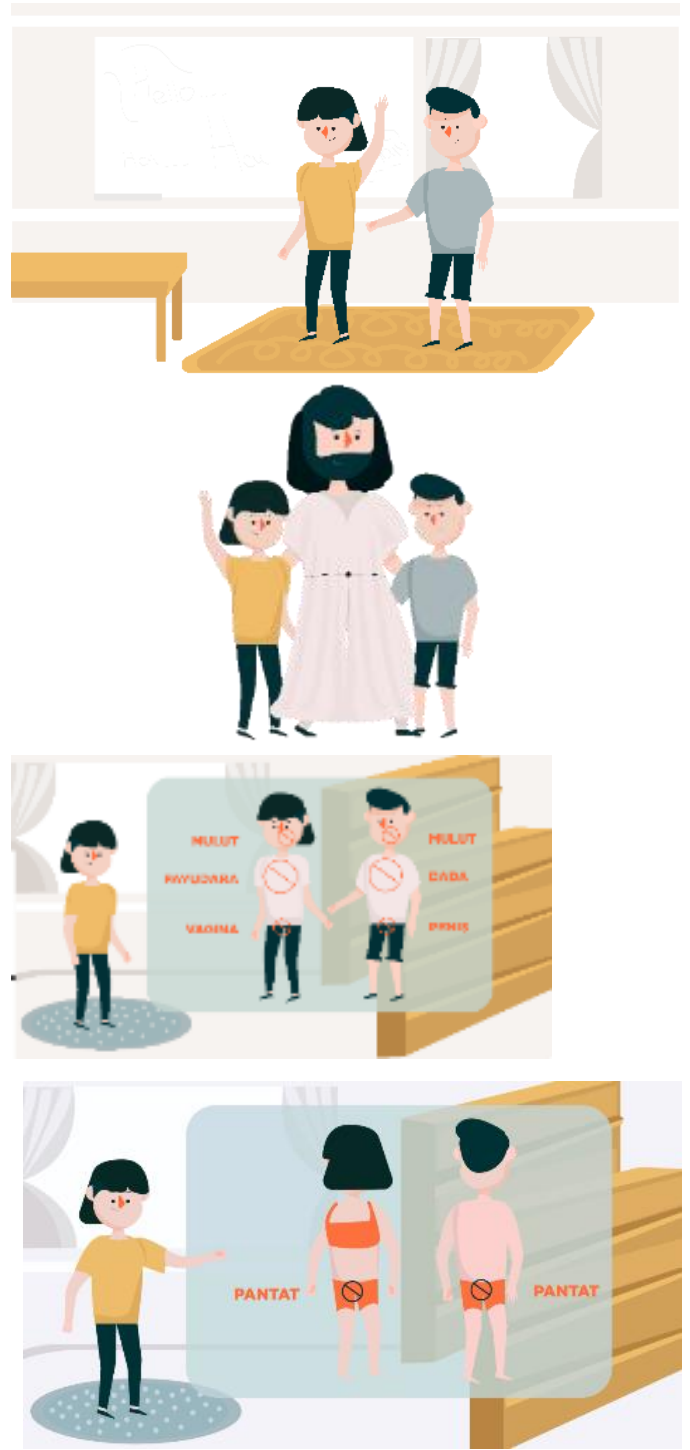

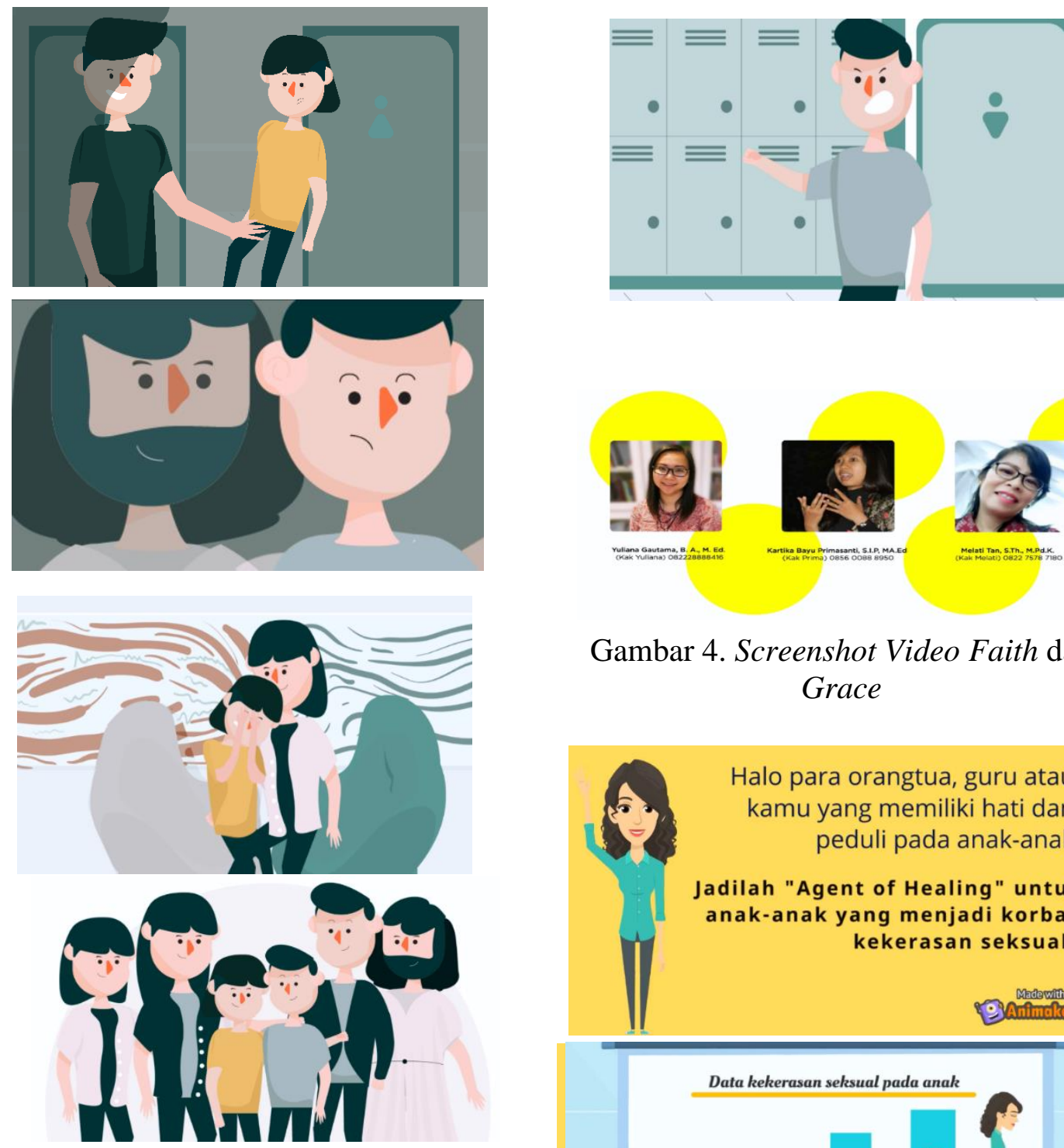

Gambar 4. Screenshot Video Faith dan Grace
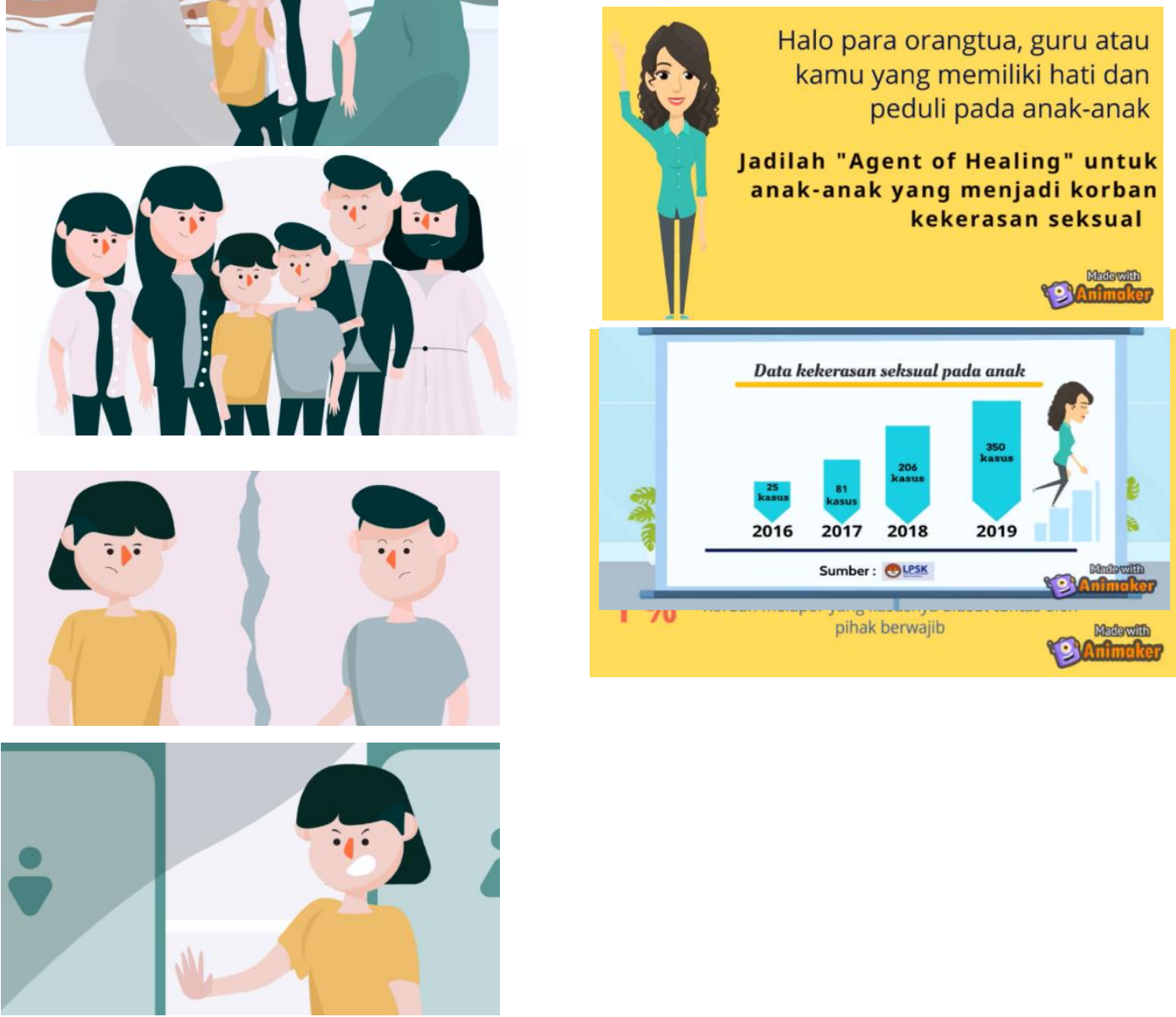
Aletheia Christian Educators Journal, vol. 2, No. 1, April 2021, 105-124
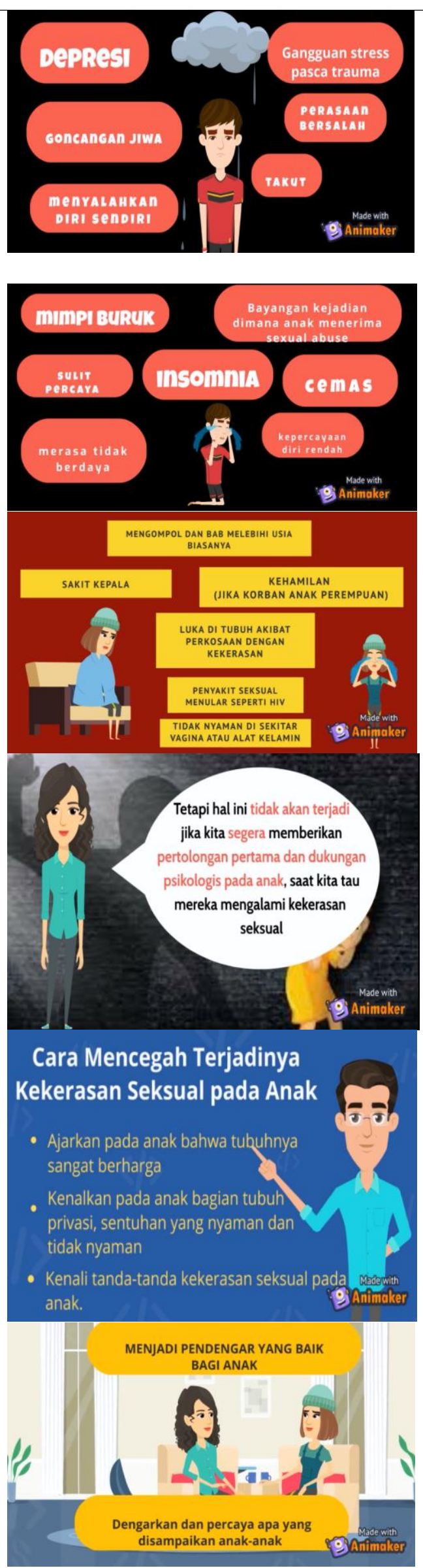
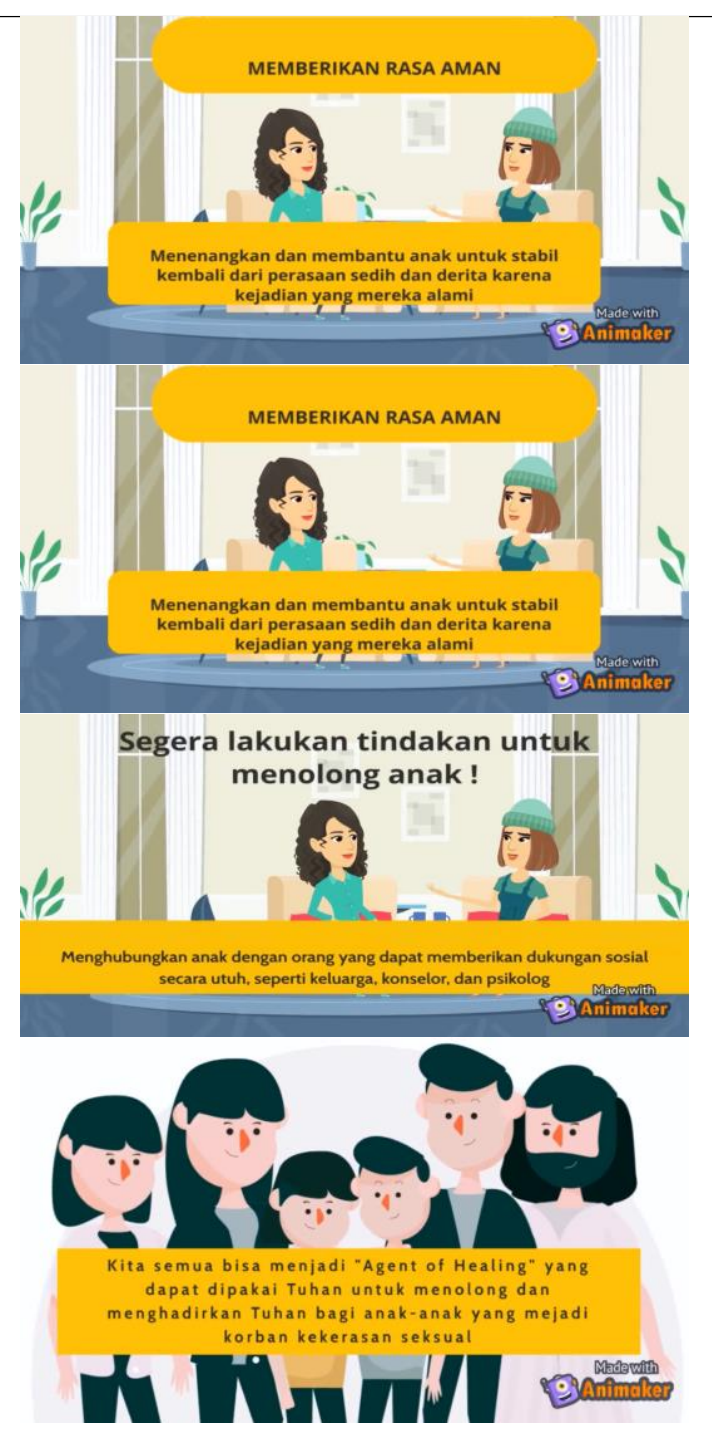

Gambar 5. Screenshot Video Darurat Kekerasan Seksual pada Anak.

\section{Kesimpulan}

Dalam mengerjakan perancangan video yang telah dibuat ini, penulis dapat mengambil beberapa kesimpulan yaitu :

1. Beberapa konselor dan psikolog anak telah memvalidasi video ini layak dipakai, dan bisa menjadi salah satu alat untuk menolong anak korban kekerasan seksual. Kelak video ini akan dipakai para pakar juga untuk menolong anakanak korban sexual abuse.

2. Melalui video ini, dampak traumatis sexual abuse betrayal yang menimbulkan masalah besar mengenai kepercayaan dalam diri anak dapat teratasi. Video ini sangat menolong anak-anak korban 
Gemilang: Menolong Anak Korban Sexual Abuse Mengatasi Traumanya dengan Video Psikoedukasi sebagai Psychological First Aid sesuai Alkitab

sexual abuse untuk berani menceritakan pengalamannya. Bercerita bukanlah hal yang mudah bagi anak-anak korban sexual abuse. Melainkan dibutuhkan keberanian yang sangat besar bagi anak korban sexual abuse untuk menceritakan pengalaman sexual abuse yang ia alami.

3. Video ini membantu pemulihan gambar diri bagi anak-anak korban sexual abuse, yang awalnya mereka merasa diri tidak berharga tetapi setelah menonton video ini mereka merasa dirinya sangat berharga bagi Tuhan Yesus.

4. Video ini mengedukasi anak-anak tentang sexual abuse dan cara mencegah agar sexual abuse tidak terulang kembali.

\section{Daftar Pustaka}

Allen, Brian; Brymer Melissa J; Steinberg, Alan M; Verbern Eric M; Jacobs Anne; Spier Anthony H; Spynoos Robert S. (2020, August 22). Perception of Psychological First Aid Among Providers Responding to Hurricanes Gustav and Ike. Journal Of Traumatic Stress, vol 23, 509-513.

Brymer, M., Jacobs, A., Layne, C., Pynoos, R., Ruzek, J., Steinberg, A., $\quad \ldots \quad \& \quad$ Watson, $P$. (2006).Psychological first aid: Field operations guide . National Child Traumatic Stress Network and National Center for PTSD. Retrieved from www. nctsn. org and www. ncptsd. va. gov.

Bujuri, Dian. (2018). Analisis Perkembangan Kognitif Anak Usia Dasar dan Implikasinya dalam Kegiatan Belajar Mengajar. LITERASI (Jurnal

$\begin{array}{lcc}\text { Ilmu Pendidikan). } & \text { 9. } 37 . \\ \text { 10.21927/literasi.2018.9(1).37-50. }\end{array}$

Collins, G. R. (2007). Christian counseling : a comprehensive guide, third edition. USA: Tyndale house.

Damayanti, F. E., \& Avelina, Y. (2019, January). Keefektifan pyschological first aid sebagai pertologan pertama pada korban bencana \& trauma in prosiding seminar nasional 2018 "peran dan tanggung jawab tenaga kesehatan dalam mendukung program kesehatan nasional" (pp. 117-124).

Das, M., \& Mohanty, N. (2018). Physical activity and play as a medium of psychological first aid (PFA) leading to psychosocial care for building resiliency and helps to overcome trauma in emergency situations. Clinical and Experimental Psychology, 4, 184.

Djera, A. T. (2015). Studi spiritual feminis terhadap tamar dalam II samuel 13:122 (Undergraduate thesis, Universitas Kristen Satya Wacana,2015). Retrieved from https://repository.uksw.edu/

Erianti, S., \& Adila, D. R. (2019).Penyuluhan Berbasis Multimedia dalam Mencegah Perilaku Seks pada Remaja di SMU Negeri 11 Pekanbaru. Jurnal Pengabdian Masyarakat Multidisiplin, 3(2), 139145.

Finkelhor, D., \& Browne, A. (1985). The traumatic impact of child sexual abuse: A conceptualization. American Journal of orthopsychiatry, 55(4), 530-541.

Fritz, G. K. (2017). The National Child Traumatic Stress Network. The Brown University Child and Adolescent Behavior Letter, 33(9), 8-8.

Fowler, J. (1991). Weaving the new creation. New York: Harper Collins.

Giller, E. (1999). What is psychological trauma? The Sidran Institute.

Ginting, M. N. K. (2020). PELECEHAN SEKSUAL PADA ANAK: DITINJAU 
Aletheia Christian Educators Journal, vol. 2, No. 1, April 2021, 105-124

DARI SEGI DAMPAK DAN PENCEGAHANNYA.

JURNAL PIONIR, 7(3).

Maharani, L. N., \& Sanyata, S. (2019). Media for sex education in elementary school: Which one is better?. Psychology, Evaluation, and Technology in Educational Research, 1(2), 117124.

Noviana, I. (2015). Kekerasan seksual terhadap anak: dampak dan penanganannya. Sosio Informa, 1(1).

Nurwati, N., \& Krisnani, H. (2019). DAMPAK

DAN

PENANGANAN

KEKERASAN

SEKSUAL

ANAK DI

KELUARGA. Prosiding

Penelitian dan Pengabdian kepada Masyarakat, 6(1), 10-20.

Ocviyanti, D., \& Khusen, D. (2018). Penanganan Holistik pada Kasus Pelecehan Seksual pada Anak. Journal of The Indonesian Medical Association, 68(4), 176179.

Primasanti，K.B. (2019) Gracefull child : menghadirkan anak-anak yang hidup dalam anugerah Tuhan. Yogyakarta, Indonesia :Pmbr Andi.

Riski, P. (2020, July 24). Saatnya persenjatai anak dengan pengetahuan tentang melawan kekerasan. VOA Indonesia. Retrieved from https://www.voaindonesia.com/ a/saatnya-persenjatai-anakdengan-pengetahuan-tentangmelawan-

kekerasan/5516007.html

Sphere Project. (2004). Humanitarian charter and minimum standards in disaster response. Sphere Project.
Susanto, M. I. (2019). TA: Perancangan Buku Ilustrasi Psychological First Aid dengan Teknik Digital Painting sebagai Media Komunikasi Trauma Healing Anak Usia 6-12 Tahun Korban Bencana Kebakaran (Doctoral dissertation, Institut Bisnis dan Informatika Stikom Surabaya).

Terlonge, P. (2013). Psychological first aid for children. Save the children. Retrieved October 4, 2020 from https://resourcecentre.savethechildren. net/sites/default/files/documents/final_ pfa.pdf

Wahyuni, S. (2016). Perilaku Pelecehan Seksual dan Pencegahan Secara Dini Terhadap Anak. JURNAL RAUDHAH, 4(2).

Westerhoff, J. H. (1976). Will our children have faith?. New York: Seabury Press.

World Health Organization. (2003). Guidelines for medico-legal care of victims of sexual violence.

Yantzi, M. (2009). Kekerasan Seksual Dan Pemulihan. BPK Gunung Mulia 